\title{
Methods for Quantification of the Decline Phenomenon and Determination of the Vulnerability Degree for the Oak Stands in Northwestern Transylvania, Romania
}

\author{
Vasile ŞIMONCA ${ }^{1,2}$, Ioan OROIAN ${ }^{3}$, Dănuț CHIRA ${ }^{4}$, Ioan TĂUT ${ }^{1,2 *}$ \\ ${ }^{1}$ University of Agricultural Science and Veterinary Medicine, Faculty of Horticulture, Forestry Department, Cluj-Napoca, Calea Mănăștur 3-5 \\ Str., 400372 Cluj-Napoca, Romania; simoncavasile@gmail.com \\ ${ }^{2}$ National Institute for Research and Development in Forestry "Marin Drăcea", Cluj-Napoca Research Station, 65 Horea Str., Cluj-Napoca, \\ Romania; ioan_taut90@yahoo.com ("correspondingauthor) \\ ${ }^{3}$ University of Agricultural Science and Veterinary Medicine, Faculty of Agriculture, Calea Mănăștur 3-5 Str., 400372 Cluj-Napoca, \\ Romania;ioroian@usamvcluj.ro \\ ${ }^{4}$ National Institute for Research and Development in Forestry "Marin Drăcea", Braşov Research Station, 26 Cloṣca Str., Braşov, \\ Romania; chira@dsbv.ro
}

\begin{abstract}
The decline phenomenon of stands can be defined as the totality of effects that damage the normal vegetation state of trees and stands. There are two types of decline, the acute one, with fast development, and the chronical one, with slow development in space and time. The accurate capture of the phenomenon has direct implications for the forest management measures. A first step in this direction is the analysis of the development type and of its dynamics. Forests which have Quercus species in composition are affected more by this phenomenon. There were identified oak stands presenting decline phenomenon in 9 Forest Districts in Northwestern Transylvania and 22 experimental plots were analyzed. These plots were located in middle aged stands that were affected in different ways. The study was performed during 2013-2015 and focused on crown level assessments of trees, taking into consideration the shape and size, defoliations, percentage of dead or missing slender branches, number of dead thick branches, presence of epicormic branches or dormant buds on the stem, presence of pathogens or pests. These elements were used for calculating some technical indicators of the health and vegetation state: degree of dieback, damage and devitalization, synthetic index damage, annual mortality rate. In 7 out of 22 stands, the overcoming of the incipient stage and beginning of active dieback stage was observed. The strongest correlation occurred between the annual mortality rate and the synthetic index damage.
\end{abstract}

Keywords: decline stands, defoliation, devitalization, health state, oak, synthetic index damage

\section{Introduction}

Quercus species, especially common oak (Quercus robur) and sessile oak (Quercuspetraea), core species for most of the broadleaf forests in Europe, show, in many areas, structural and ecological degradation phenomena and symptomatology. The negative impact on forests of environmental factors was, in Romania, similar to the one described in most European countries, and there existed numerous situations in which devitalization, deterioration of vegetation state and occurrence of abnormal diebacks started to become frequent (Rossnev et al., 1994; Woo, 2009; Sonesson and Drobyshev, 2010; Popa et al., 2013; Jankowiak et al., 2014; Keca et al., 2016).
The fast development of symptoms, their space spreading and their action upon forest species lead to the socalled syndrome, "the unknown forest decline" (Badea and Tănase, 2003). The aspects of this phenomenon, a consequence of the harmful effects of biotic and abiotic factors could not be explained through research conducted at that time. Finally, the decline of forest ecosystems was assigned to the effects of the negative action of atmospheric pollution, highlighting the relations between cross-border pollutant deposits and main components of the ecosystem, climate changes or virulence increase of some biotic agents (Alexe, 1986; Jung and Blaschke, 1996; Desprez-Loustau et al., 2006; Trudic et al., 2013). 
624

Currently, it is considered that what is generally known as "dieback" or "forest decline" is in fact a complex phenomenon, caused by the evolution in time of the environmental conditions from forest biocoenosis (Millar and Stephenson, 2015). This phenomenon can be assigned to some structural or functional disorders, in which several categories of disturbing and harmful factors concur and interact in different ways and directions, leading to weakening of tree's vigor and culminating with their death. In a general meaning, stand decline phenomenon can be defined as the totality of effects that damage the normal vegetation state of trees and thus, of the stands (Delatour, 1983; Thomas et al., 2002; Pap et al., 2014a).

There are several definitions and meanings of the terms forest decline and devitalization. These terms are not standardized, being subject to future debates and their definition is still under development. However, it is unanimously accepted that there are two types (models) of decline - an acute one, with fast development, and a chronical one, with slow development in space and time (Denman, 2014). The combination of factors that causes disequilibrium varies on area, year, forest type, leading to a varied symptomatology, which is strongly influenced by the environment and numerous biological interactions (Marcu, 1986; Führer, 1998; Thomas, 2008; Andersson et al., 2011; Santini et al., 2013; Sohar et al., 2013; Dănescu et al., 2015).

The effects of these decline phenomena are expressed through symptoms (defined as host responses) and evidence (traces left by pest and pathogen attacks on host trees), which in most of the cases occur as a combination. These can develop sequentially or simultaneously and can have an individual or a cumulative action on development in host's environment, whose sensibility increases in time (Tulic and Bijak, 2016). The factors involved act on different levels, simultaneously or one at a time (Raftoyannis et al., 2008; Brown et al., 2017).

Therefore, at crown level the effects of prolonged draughts, late freezes, defoliations, pathogen attacks, pollution, etc. are felt. The short and medium term effects are the reduction of photosynthesis, nutritional disequilibria, having as result the loss of the crown. At stem level, xylophagous insects and fungi, extreme heat or frost generate disturbances of metabolism and conductivity, reduce primary resistance and cause diminutions of the rhythm of cambial activity, while at rootlet system level, draughts, stagnant water, acidification, nutritional disequilibria, pathogenic fungi and bacteria, which most often cause problems of assimilation or even the reduction / complete stop of symbiotic relationships (Gibbs and Greig, 1997; Csóka et al., 1999; Hilszczański and Sierpinski, 2006; Fodor et al., 2011; Pešková et al., 2015; Vuts et al., 2016; Denman et al., 2017).

Long term observations performed worldwide lead to the conclusion that in the manifestation of dieback (decline) phenomenon of oak stands three phases can be identified: a first phase of stand weakening, due to either unfavorable climate conditions (prolonged draughts, water stagnation, late frosts), either repeated defoliations followed by the attack of Microsphaera alphitoides; a dieback phase, with different intensities of manifestation, when the installation of pathogens is favored and a phase of tree death, which can be slow or fast (Ciesla and Donembauer, 1994; Neuwirth et al., 2007; Voelker et al., 2008; Hajji et al., 2009; Kunca et al., 2010; Szewczyk et al., 2011, Pap et al., 2014b; Salle et al., 2014).

For the presented aspects, a highlight of the complex of provoking, favoring, aggravating or compensatory factors involved in oak debilitations was necessary to be made in Northwestern Transylvania forests. A first step in this direction is the analysis of the development model and of the dynamics of this phenomenon. In order to achieve this, several predictors of the decline have to be analyzed. These predictors show the modifications that occur in the health state, under different aspects (Haring et al., 1984; Kunca et al., 2010).

In the hereby study, the modifications that occur in stand health state were assessed. Observations performed in successive years presented the possible direction and size of these modifications at stand level.

\section{Materials and Methods}

\section{Study area}

The investigations were performed in Northwestern Transylvania, in stands where the core species are Quercus robur and/or Quercus petraea and in which several symptomatology specific to the decline phenomenon manifested, or those stands that are prone to decline due to adverse factors of biotic or abiotic nature (repeated defoliations, bark beetles, leaf and vascular diseases, late frosts and repeated draughts, etc.) (Table 1). Only middle aged and superior - medium productivity stands were selected.

\section{Data set}

In each of these stands, a 0.5 ha experimental plot was installed. All trees belonging to I-III Kraft classes were inventoried and numbered. For each tree, the following characteristics were analysed: Kraft class, crown shape and size, average defoliation percentage on a $5 \%$ scale, vegetation state, percentage of dead or missing slender branches, number of dead thick branches in the upper third of the crown, presence of epicormic branches or dormant buds on the stem, presence of pathogens or pests, together with a description of the encountered defects or degradations. The observations were repeated between 2013 and 2015 and the assessment period was June-August. The descriptive characteristics were converted into numerical characteristics (Table 2).

Stand evolution was analyzed and compared using the following indicators:

Degree of damage: $G v=(n 2+n 3+n 4) \times 100 / N$

Degree of dieback: $G u=(0.5 \times n 3+n 4) \times 100 / N$

Degree of devitalization: $G d e v=(G u+G v / 10) / 2$, where $\mathrm{n}$ - number of trees belonging to the class: $n 10-10 \%$ (very low damaged, defoliated tree), $n 211-25 \%$ (low damaged, defoliated tree), $n 3$ 26-60\% (medium damaged, defoliated tree), $n 4>60 \%$ (heavy damaged, defoliated tree), $N-$ number of analyzed trees.

The degree of damage and of dieback are predictors usually used in the assessment methodology of forest health state in Romania (Technical Regulations of Forest 
Table 1. Study plots characteristics

\begin{tabular}{|c|c|c|c|c|c|c|c|c|}
\hline \multirow[b]{2}{*}{ No. } & \multirow{2}{*}{$\begin{array}{l}\text { County Forest } \\
\text { Administration }\end{array}$} & \multirow[b]{2}{*}{ Forest district } & \multirow{2}{*}{$\begin{array}{c}\text { Management } \\
\text { unit/Compartiment }\end{array}$} & \multicolumn{5}{|c|}{ Stand characteristics } \\
\hline & & & & Composition & $\begin{array}{c}\text { Productivity } \\
\text { class }\end{array}$ & $\begin{array}{l}\text { Crown } \\
\text { density }\end{array}$ & Age & Damage factor \\
\hline 1 & \multirow{4}{*}{ Satu Mare } & \multirow{2}{*}{ Satu Mare } & I, $56 \mathrm{~A}$ & $8 \mathrm{Qr} 2 \mathrm{Ca}$ & II & 0.9 & 30 & repeated defoliations \\
\hline 2 & & & $\mathrm{I}, 34 \mathrm{C}$ & $7 \mathrm{Qr} 3 \mathrm{Ca}$ & II & 0.6 & 80 & grouped diebacks \\
\hline 3 & & \multirow{2}{*}{ Livada } & $\mathrm{I}, 34 \mathrm{~A}$ & $8 \mathrm{Qr} 2 \mathrm{Fr}$ & II & 0.8 & 50 & grouped diebacks, site conditions \\
\hline 4 & & & $\mathrm{I}, 69$ & $7 \mathrm{Qr} 3 \mathrm{Fr}$ & II & 0.8 & 50 & grouped diebacks, site conditions \\
\hline 5 & \multirow{5}{*}{ Maramureș } & \multirow{3}{*}{ Şomcuta Mare } & IV, 34 & $8 \mathrm{Qr} 2 \mathrm{Ca}$ & II & 0.8 & 40 & repeated defoliations \\
\hline 6 & & & IV, 55B & 7Qr 3Ca & II & 0.9 & 80 & repeated defoliations \\
\hline 7 & & & IV, 65 & 10 Qr & II & 0.6 & 80 & repeated defoliations \\
\hline 8 & & \multirow{2}{*}{ Ulmeni } & I, 29 C & $10 \mathrm{Qp}$ & I & 0.7 & 80 & grouped diebacks \\
\hline 9 & & & $\mathrm{I}, 30 \mathrm{D}$ & 8Qp $2 \mathrm{Ca}$ & II & 0.6 & 40 & isolated diebacks \\
\hline 10 & \multirow{5}{*}{ Bistrita } & \multirow{2}{*}{ Bistrita } & I, $40 \mathrm{~A}$ & 5Qr 5Qp & III & 0.8 & 60 & abiotic factors \\
\hline 11 & & & VII, 151B & $10 Q p$ & II & 0.7 & 60 & abiotic factors \\
\hline 12 & & \multirow{3}{*}{ Beclean } & IV, 140B & $10 \mathrm{Qp}$ & II & 0.8 & 80 & pathogens \\
\hline 13 & & & IV, 141B & $9 \mathrm{Qp} 1 \mathrm{Ca}$ & III & 0.8 & 60 & abiotic factors \\
\hline 14 & & & IV, $154 \mathrm{C}$ & $10 \mathrm{Qp}$ & II & 0.7 & 40 & abiotic factors \\
\hline 15 & \multirow{3}{*}{ Cluj } & Cluj & II, $5 \mathrm{~A}$ & 7 Qp $3 \mathrm{Ca}$ & III & 0.8 & 50 & abiotic factors \\
\hline 16 & & \multirow{2}{*}{ Gherla } & III, $64 \mathrm{~A}$ & 7 Qp $3 \mathrm{Ca}$ & III & 0.7 & 95 & pathogens \\
\hline 17 & & & III, $65 \mathrm{C}$ & $10 \mathrm{Qp}$ & III & 0.8 & 55 & pathogens \\
\hline 18 & \multirow{5}{*}{ INCDS } & \multirow{5}{*}{ Lechința } & $\mathrm{I}, 63 \mathrm{~B}$ & $10 \mathrm{Qp}$ & II & 0.8 & 80 & isolated diebacks \\
\hline 19 & & & $\mathrm{I}, 65 \mathrm{C}$ & $9 \mathrm{Qp} 1 \mathrm{Ca}$ & III & 0.8 & 60 & isolated diebacks \\
\hline 20 & & & II, $21 \mathrm{~B}$ & $10 \mathrm{Qp}$ & III & 0.8 & 75 & Abiotic factors, defoliations \\
\hline 21 & & & IV, 29 D & $7 \mathrm{Qp} 3 \mathrm{Ca}$ & III & 0.7 & 50 & xylophagous insects, defoliations \\
\hline 22 & & & $\mathrm{~V}, 28 \mathrm{D}$ & $7 \mathrm{Qp} 3 \mathrm{Ca}$ & III & 0.8 & 75 & xylophagous insects, defoliations \\
\hline
\end{tabular}

Qr-Quercus robur, $\mathrm{Qp}$ - Ouercuspetraea, Ca- Carbinus betulus, Fr- Fraxinus excelsior

Table 2. Grading scale of the analyzed parameters

\begin{tabular}{ccc}
\hline Parameter analyzed & Value & Significance \\
\hline \multirow{2}{*}{ Crown shape } & 0.5 & very asymmetric \\
& 1 & asymmetric \\
& 2 & symmetric \\
\hline Crown size & 0.5 & very narrow \\
& 1 & narrow \\
& 2 & medium \\
& 3 & wide \\
Vegetation state/ vitality & 3.5 & very wide \\
& 0 & healthy, active \\
& 3 & weakened, moderately active \\
& 3 & deteriorated, unthrifty \\
Epicormic branches & 1 & devitalized, ongoing dieback, dead \\
\hline & 2 & with dormant buds \\
\hline
\end{tabular}

Protection, annex IV E1a). The degree of devitalization is a proper assessment parameter, calculated as a weighted average between the previous two. The ratio Gv/10 was adopted for value uniformization. Another proposed indicator of the decline is the synthetic index damage - Syn (Dmyterko and Bruchwald, 2000; Kuzminski and Wtyklo, 2014) which involves placing each tree in a devitalization class according to the general aspect of the crown, especially third order branches from the upper part of the crown (Fig. 1) and the calculation of a synthetic damage index for the whole stand, using the formula:
Syn $=(0.03 \times \Sigma D e f+\Sigma W i t) /(2 \times N)$

where: Def - defoliation/dieback, Wit - vitality class, $\mathrm{N}$ number of analyzed trees.

This index can take values between 0 and 3 . An increase in value shows a decrease of vitality and a degradation of the health and vegetation state.

The annual mortality rate for trees belonging to I-III Kraft classes was determined using the formula of Stringer $e t$ al. (1989), Sheil and May (1996):

$$
R m=1-(\mathrm{Na} / \mathrm{No}) 1 / t
$$

where $\mathrm{Na}$ - current number of trees, $\mathrm{No}$ - initial number of trees, $\mathrm{t}$ - time (in years).

The values obtained were compared with theoretical values provided by production tables (Giurgiu and Drăghiciu, 2004).

The Mann- Whitney test was used to determine the significance of the difference between values given by each predictor in the two years of observations, and the obtained values were compared with table values of $\mathrm{z}, \mathrm{p}, \mathrm{U}$. The correlation was determined using the Spearman test (rank correlation), calculated using the formula:

$$
\rho=1-\frac{6 \sum D^{2}}{N^{3}-N}
$$

where D - difference between the rank of the two variables, $\mathrm{N}$ - number of pairs in ascending order.

The differences obtained in the two observations years were expressed in a percentage form, and the correlation intensity was verified using the $t$ test (Student).

In order to determine the significance, the obtained values were compared to theoretical values for the significance degree of $95 \%$. 


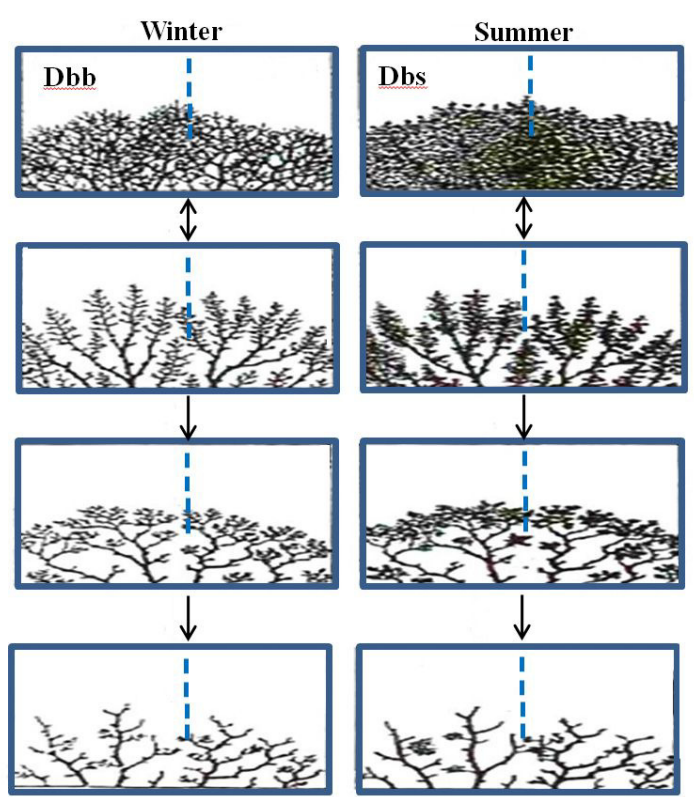

(Dbb-common oak, Dbs-sessile oak) degree 0 - healthy, active tree, all the upper part of the crown is made of a thick network of first order branches, space is filled by crown ramification, no gaps

degree 1 - weakened tree, missing structures occur in the upper part of the crown, several gaps inside the crown (because of dieback of some slender branches)

degree 2 - deteriorated tree, flattened structures at crown's limit, big gaps, the upper part is flattened, dormant buds occur

degree 3 - severely devitalized tree (in decline) with dead thick branches, crown decomposed in isolated parts, viable slender branches in isolated groups

Fig. 1. Assessment key of tree vitality for the determination of synthetic index damage (by Roloff, quoted by Dmyterko and Bruchwald, 2000)

\section{Results and Discussion}

According to the chosen research method, in each experimental stand the degree of decline was determined through observations of tree crowns. A series of synthetic indexes was obtained, which show both at a general and at a particular level some aspects regarding the vegetation, health and decline states (Dubravac and Dekanic, 2009).

\section{Condition of stands}

The crown is the most accurate and most easily to assess predictor of tree decline. A tree is considered healthy if it belongs to the upper level (I-III Kraft) and has a welldeveloped, wide and relatively symmetric crown. By crown size, according to the assessment scale, the analyzed stands showed a normal situation, having values that place them in the interval 1.8- 2.8 (medium to wide crown). It can be observed (Table 3) that the lowest value (1.685) was registered in Somcuta Mare, I, 34, with the core species is Quercus robur, while the highest value (2.853) was noted in Bistrița, I, 40A, where the core species is Quercus petraea.

The crown shape in 9 of the analyzed stands was closer to asymmetric (the lowest value -1.214 , Satu Mare, I, 56A), while the rest of the stands had normal values. It was to be noted that the lowest values were registered in stands that were harmed by the attacks of defoliating insects. Even more, 5 stands, all belonging to oak subarea, registered below the average values for both crown size and shape.

The presence of epicormic branches at medium ages, a sign of structural degradations in the stand, related mainly to density, was detected in 2 of the analyzed stands (Satu Mare, I, 34C and Șomcuta Mare, IV 34).

The investigation of the dead thick branches $(>10 \mathrm{~cm})$ in the upper third of the crown had significant differences over the study interval; the obtained values were $0.85 \pm 0.51$ in 2013 and became $1.3 \pm 0.51$ in 2015 . Significant changes were recorded for 4 of the analyzed stands (Satu Mare, I, 56A; Bistrița, VII, 151B; Beclean, IV 154C; Lechința, I,
63B).

Never the less, the dead slender branches remained constant $(11.54 \pm 3.79$ in 2013 and $12.53 \pm 4.82$ in 2015) for the analyzed time interval. The largest increase was recorded in Livada, I, 34A, from $13.8 \%$ to $18.2 \%$, while in 10 of the analyzed situations a slight improvement (3-4\%) was recorded.

Stands that presented percentages of up to $20 \%$ in 2013 had lower values in 2015, thus increases of this indicator were recorded only in isolated situations.

Regarding the recorded defoliations, phenomenon translated into the loss of leaves due to biotic or abiotic factors, thus into the increase of crown's transparence degree. This is the most frequent and most easily to quantify symptom at tree and stand level. The average value for the analyzed stands was $14.4 \pm 7.5$ in 2013 and $17.9 \pm 8.4$ in 2015. This phenomenon, due to which trees slow their growth and suffer disturbances of the nutritional regime, manifested with the same intensity in the two years of observations except for the following stands: Şomcuta Mare, IV, 34; Beclean, IV, 140B; Lechința, IV, 29D and V, 28D. These stands changed from a low intensity to medium intensity. The observed defoliation was due to several attacks of Euproctis chrysorrhoea in S,omcuta Mare, Melolontha melolontha and Agrilus sp. in Lechința and mildew symptoms in Beclean.

\section{Determination of the vulnerability degree}

The dynamics of the health and vegetation state of stands, expressed through synthetic indicators that use a layering of individual values obtained in classes of damage, shows the following: if all trees that are above a critical degree of $10 \%$ damage/defoliations are taken into consideration, in 2013 there were 3 highly damaged stands (Ulmeni, I, 29C; Gherla, II, 5A; Lechința, V, 28D), 10 were medium damaged and 9 had a low damage. It is to be noted that 2 stands (Lechința, V, 29 and II, 21B) were at the limit between healthy and weakly affected (Fig. 2). 
Table 3. Crown parameters analyzed as predictors of tree decline in the studied stands

\begin{tabular}{|c|c|c|c|c|c|c|c|c|c|c|c|}
\hline \multirow[t]{2}{*}{ No } & \multirow[t]{2}{*}{ Forest District } & \multirow[t]{2}{*}{$\begin{array}{c}\text { Manage ment } \\
\text { Unit/com- } \\
\text { partment }\end{array}$} & \multirow[t]{2}{*}{ Crown size } & \multirow{2}{*}{$\begin{array}{l}\text { Crown } \\
\text { shape }\end{array}$} & \multirow[t]{2}{*}{$\begin{array}{c}\text { Epicor mic } \\
\text { bran } \\
\text { ches }\end{array}$} & \multicolumn{2}{|c|}{$\begin{array}{l}\text { Number of dead } \\
\text { thick branches } \\
\quad(>10 \mathrm{~cm})\end{array}$} & \multicolumn{2}{|c|}{$\begin{array}{l}\text { Average percentage of } \\
\text { dead slender branches }\end{array}$} & \multicolumn{2}{|c|}{ Defoliation (\%) } \\
\hline & & & & & & 2013 & 2015 & 2013 & 2015 & 2013 & 2015 \\
\hline 1 & \multirow{2}{*}{ Satu Mare } & $\mathrm{I}, 56 \mathrm{~A}$ & 2.22 & 1.214 & 0.56 & 0.75 & 2.04 & 12.34 & 14.63 & 28.7 & 26.3 \\
\hline 2 & & I, 34C & 1.98 & 1.44 & 1.34 & 1.29 & 0.72 & 13.56 & 13.36 & 21.3 & 28.7 \\
\hline 3 & \multirow{2}{*}{ Livada } & $\mathrm{I}, 34 \mathrm{~A}$ & 2.21 & 1.65 & 1.12 & 1.22 & 0.96 & 13.82 & 18.23 & 12.2 & 15.5 \\
\hline 4 & & $\mathrm{I}, 69$ & 1.896 & 1.23 & 0.99 & 1.78 & 1.44 & 17.55 & 20.21 & 15.5 & 12.2 \\
\hline 5 & \multirow{3}{*}{ Şomcuta Mare } & IV, 34 & 1.685 & 1.31 & 1.64 & 1.39 & 1.79 & 15.00 & 11.25 & 15.7 & 25.2 \\
\hline 6 & & IV, 55B & 1.858 & 1.48 & 0.97 & 0.92 & 1.26 & 18.01 & 22.35 & 22.6 & 19.4 \\
\hline 7 & & IV, 65 & 2.08 & 1.58 & 0.13 & 1.02 & 1.01 & 10.46 & 14.11 & 15.5 & 15.4 \\
\hline 8 & \multirow{2}{*}{ Ulmeni } & $\mathrm{I}, 29 \mathrm{C}$ & 1.85 & 1.40 & 0.60 & 1.69 & 2.32 & 15.57 & 17.25 & 25.2 & 22.5 \\
\hline 9 & & $\mathrm{I}, 30 \mathrm{D}$ & 2.35 & 1.58 & 0.38 & 0.36 & 0.34 & 5.58 & 4,25 & 5.7 & 15.7 \\
\hline 10 & \multirow{2}{*}{ Bistrița } & $\mathrm{I}, 40 \mathrm{~A}$ & 2.85 & 1.77 & 0.29 & 0.27 & 1.92 & 7.71 & 8.45 & 5.4 & 9.8 \\
\hline 11 & & VII,151B & 2.26 & 1.56 & 0.33 & 0.44 & 1.86 & 10.11 & 9.28 & 7.2 & 15.4 \\
\hline 12 & \multirow{3}{*}{ Beclean } & IV,140B & 2.65 & 1.67 & 0.17 & 0.27 & 0.76 & 12.22 & 9.89 & 4.9 & 21.6 \\
\hline 13 & & IV,141D & 1.98 & 1.59 & 0.45 & 0.35 & 0.64 & 9.84 & 9.11 & 5.2 & 11.5 \\
\hline 14 & & IV, $154 \mathrm{C}$ & 2.22 & 1.77 & 0.21 & 0.47 & 1.85 & 7.90 & 7.50 & 4.5 & 4.9 \\
\hline 15 & Cluj & II, $5 \mathrm{~A}$ & 2.67 & 1.78 & 0.17 & 1.41 & 1.79 & 8.55 & 7.65 & 9.0 & 5.1 \\
\hline 16 & \multirow{2}{*}{ Gherla } & III, 64A & 2.56 & 1.69 & 0.22 & 1.47 & 1.14 & 14.70 & 14.11 & 23.4 & 17.1 \\
\hline 17 & & III, $65 \mathrm{C}$ & 2.18 & 1.81 & 0.34 & 0.59 & 1.25 & 7.75 & 9.85 & 15.7 & 9.1 \\
\hline 18 & \multirow{5}{*}{ Lechința } & $\mathrm{I}, 63 \mathrm{~B}$ & 2.61 & 1.67 & 0.12 & 0.33 & 1.77 & 7.56 & 5.55 & 15.3 & 21.3 \\
\hline 19 & & $\mathrm{I}, 65 \mathrm{C}$ & 1.99 & 1.34 & 0.87 & 0.69 & 0.86 & 11.32 & 16.25 & 21.6 & 24.3 \\
\hline 20 & & II, 21 B & 2.44 & 1.39 & 0.34 & 0.54 & 1.75 & 11.67 & 15.56 & 9.8 & 7.2 \\
\hline 21 & & IV, $29 \mathrm{D}$ & 2.13 & 1.31 & 0.45 & 0.21 & 0.14 & 5.62 & 4.44 & 11.5 & 28.2 \\
\hline 22 & & $\mathrm{~V}, 28 \mathrm{D}$ & 2.46 & 1.76 & 0.07 & 1.25 & 1.07 & 17.21 & 14.13 & 21.5 & 37.2 \\
\hline
\end{tabular}

An increase of damaged trees was recorded in 2015, as follows: a $14 \%$ increase at Ulmeni I 29C and a 23\% increase at Lechința, V, 28D. In stand Gherla, III, 64A a strong decrease occurred, from 72 to $25 \%$ average damage percentage, that can be explained through the redistribution of cumulated frequencies on intensity categories, $80 \%$ of the trees falling in a lower damage class, and relatively reduced number of investigated trees $(\mathrm{N}=98)$.

The assessment given by the degree of dieback, indicator that takes into consideration only the highly damaged trees and half of medium damaged trees, shows that in 2013, 2 stands were medium damaged (Satu Mare, I, 34C; Ulmeni, I, 29C), while the rest were weakly affected (Fig. 3). In 2015, the stand Satu Mare, I, 34C felt into weakly affected category and the stand Lechința, V, 28D changed from weak to moderate dieback, due to an attack of Agrilus sp. bark beetles.

The degree of devitalization, which performs a diminution of importance of trees in weakly damaged category when taking into consideration the decline, had a similar distribution to the devitalization degree $(\chi 2=26.38)$, but significantly different in $2015\left(\chi^{2}=42.46\right)$ (Fig. 4). Moreover, the differences recorded in the 2 years for both predictors, expressed as a percentage, were not significant $(\chi 2$ $=26.72, \chi 20.01=32.67, \mathrm{Df}=21$ ).

The value of the Synthetic Index Damage for the analyzed trees (Fig. 5) showed that the stands Satu Mare, I, 34C; Livada, I, 34A; Somcuta Mare, IV, 55B and Ulmeni, I, 29C exceeded the incipient stage of decline and changed towards the active dieback stage. The other stands under study, despite negative phenomena highlighted by the previously mentioned descriptors, were in the healthy-incipient interval.

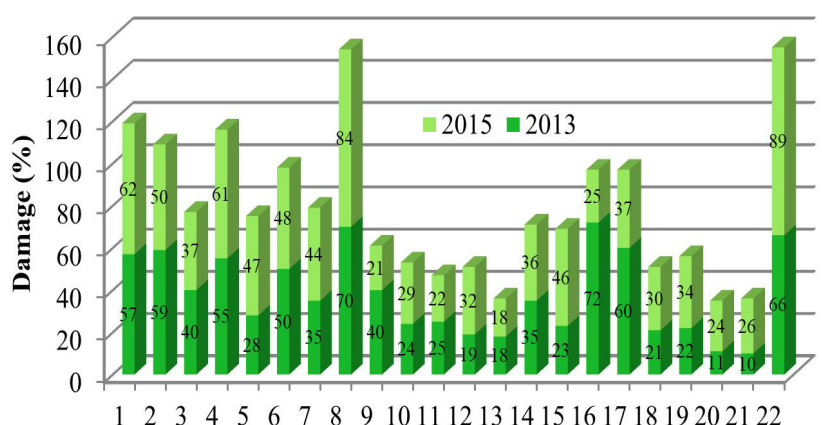

1233456678910111213141516171819202122 Location

Fig. 2. Evolution of the analyzed stands by degree of tree damage

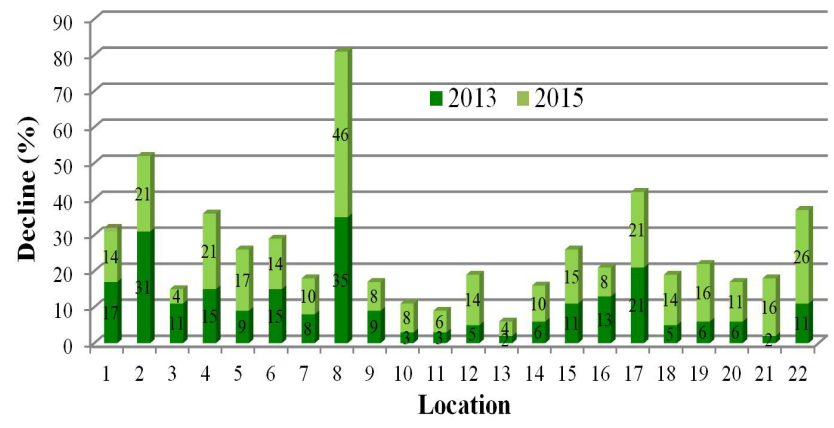

Fig. 3. Evolution of the analyzed stands by degree of dieback 


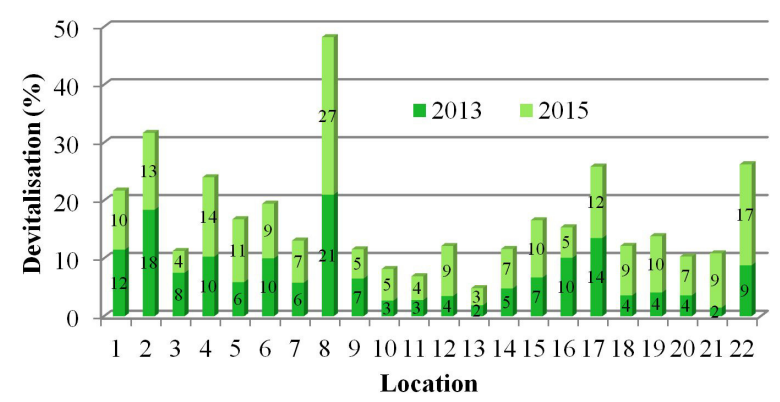

Fig. 4. Evolution of the analyzed stands by degree of devitalization

In 2015, a worsening of the vegetation state of the previously exposed stands was observed, except for Livada, I, $34 \mathrm{~A}$, where a slight improvement was noted. The slight improvement of vegetation state could also be observed for all stands in oak subarea, due to the more favorable climate conditions during 2015. However, due to the attack of Agrilus sp., in Lechința in IV, 29D and V, 28D, a significant worsening was observed. A significant change was also found in Cluj, II, 5A, due to the occurrence of dieback hornbeam and other mix species, phenomenon that was not recorded at the beginning of the study.

\section{Quantification of decline}

In order to analyze the stands for the mentioned time period, the recorded differences were analyzed; the significance was determined using the $U$ test and the link between these differences and the annual mortality rate was determined.

By analyzing the data given in Table 4, it is observed that between the two vegetation seasons under study, within the whole area taken into study, significant changes were recorded for the thick branches indicator. The changes were statistically ensured, and recorded values exceeded the 0.05 significance level in all analyzed situations.

Positive significant changes were recorded for degree of dieback, decline and devitalization predictors only for
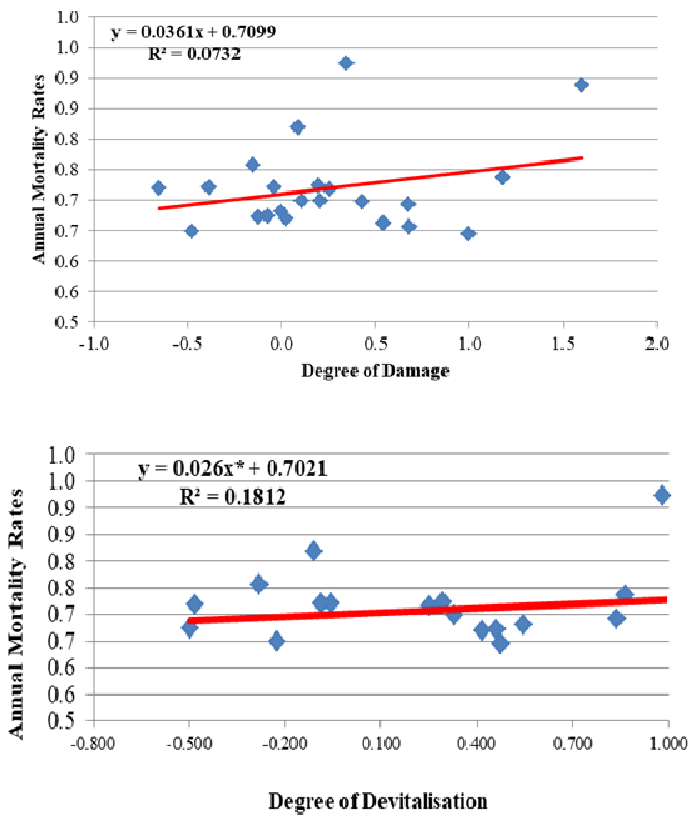

$\square 2013 \square 2015$

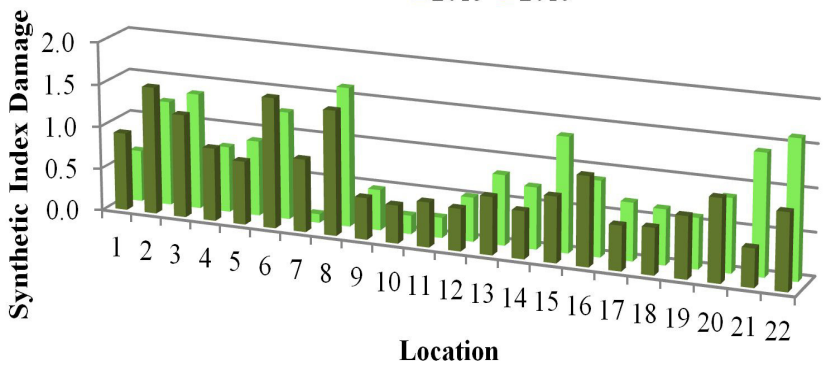

Fig. 5. Stand health state and their evolution according to the Synthetic Index Damage

stands located in the vegetation level of sessile oak. For all the other stands, positive significant changes were not statistically ensured, and the positive change of some parameters was mostly due to climate factors. These trends were also noted by McManus and Csóka (2007).

Szewczyk et al. (2011) mentioned that the mean value of defoliation showed $38.4 \%$, while the majority of trees were in the $2^{\text {nd }}$ degree defoliation class. Also, it was noticed the progressing stabilization of the disease-creating process and an improvement of the tree stand condition, however the health condition of the tree stands was not satisfactory.

The annual mortality rate took values between 0.632 and 0.754 (average $0.684 \pm 0.021$ ). The theoretical value was exceeded in 4 stands, with values between 8 and 12\% in Satu Mare and 29-34\% in Lechința (Table 5).

The annual mortality rate is most strongly correlated with stand evolution expressed through the Synthetic Damage Index $\left(r=0.479^{*}\right.$, texp $\left.=2.44\right)$ (Fig. 6). However, correlative links were also ensured with the degree of dieback $\left(r=0.430^{*}\right)$ and devitalization $(0.425)$.

It can be noted (Table 6) that there exists a positive significant correlation between the evolution of the general vegetation state and the percentage of dead slender branches and a negative significant correlation between the vegetation state and the degree of devitalization or between thick branches and annual mortality rate.
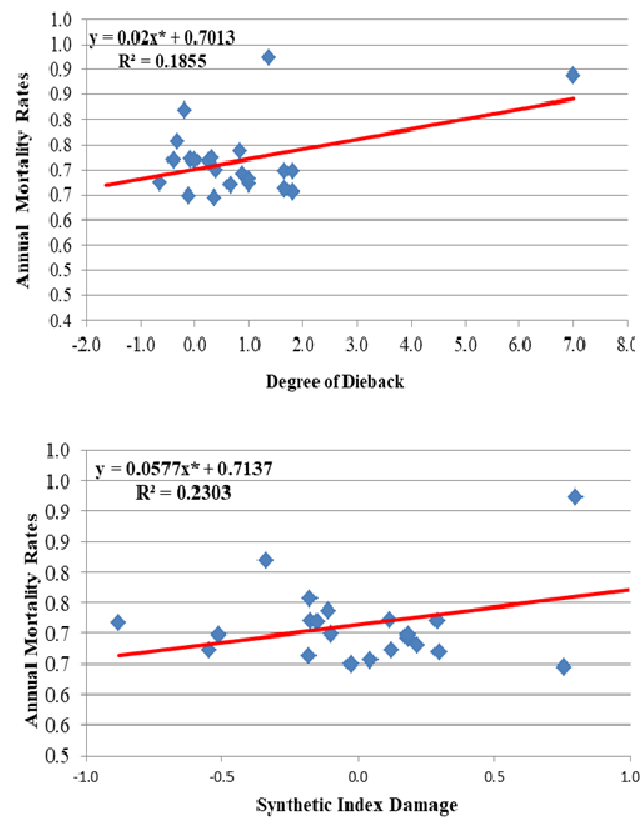

Fig. 6. Relation between annual mortality rate and percentage difference of values for the used predictors $(\mathrm{t} 0,05=2.086, \mathrm{n}=22)$ 
Table 4. Analysis of the significance of difference between values recorded in 2013 and 2015, using the U test (Mann-Withney)

\begin{tabular}{|c|c|c|c|c|c|c|c|c|c|}
\hline \multicolumn{2}{|c|}{ Analyzed characteristic } & \multirow{2}{*}{$\begin{array}{c}\begin{array}{c}\text { Degree } \\
\text { of dieback }\end{array} \\
166.5\end{array}$} & \multirow{2}{*}{$\begin{array}{c}\begin{array}{c}\text { Degree } \\
\text { of damage }\end{array} \\
218\end{array}$} & \multirow{2}{*}{$\begin{array}{c}\begin{array}{c}\text { Degree } \\
\text { of } \\
\text { devitalization }\end{array} \\
176.5\end{array}$} & \multirow{2}{*}{$\begin{array}{c}\text { Synthetic } \\
\text { Index } \\
\text { Damage } \\
192.5\end{array}$} & \multirow{2}{*}{$\begin{array}{c}\begin{array}{c}\text { Slander } \\
\text { branches }\end{array} \\
231.5\end{array}$} & \multirow{2}{*}{ 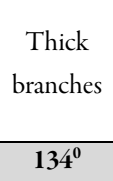 } & \multirow{2}{*}{$\begin{array}{c}\begin{array}{c}\text { Vegetatio } \\
\text { n state/ } \\
\text { vitality }\end{array} \\
292\end{array}$} & \multirow{2}{*}{$\begin{array}{c}\text { Defoliation } \\
187\end{array}$} \\
\hline \multirow{3}{*}{ For all stands } & $\mathrm{U}$ & & & & & & & & \\
\hline & $\mathrm{z}$ & -1.76 & -0.55 & -1.52 & 1.15 & -0.237 & $-2.52^{0}$ & 0.90 & -1.27 \\
\hline & $\mathrm{p}$ & 0.078 & 0.582 & 0.126 & 0.250 & 0.818 & 0.117 & 0.928 & 0.202 \\
\hline \multirow{3}{*}{$\begin{array}{l}\text { Altitudinal } \\
\text { plant } \\
\text { belt with } \\
\text { common } \\
\text { oak }^{1}\end{array}$} & $\mathrm{U}$ & 23.5 & 20.5 & 23 & 17 & 17 & $7^{*}$ & 21 & 15 \\
\hline & $\mathrm{z}$ & -0.06 & -0.44 & -0.13 & 0.89 & -0.89 & $1,99^{*}$ & 0.38 & 1.44 \\
\hline & $\mathrm{p}$ & 0.095 & 0.652 & 0.896 & 0.373 & 0.373 & 0.063 & 0.703 & 0.147 \\
\hline \multirow{3}{*}{$\begin{array}{l}\text { Altitudinal } \\
\text { plant } \\
\text { belt with } \\
\text { sessile } \\
\text { oak }^{2}\end{array}$} & $\mathrm{U}$ & 35 & 57 & 39.5 & 62.5 & 80 & 31 & 99 & 60 \\
\hline & $\mathrm{z}$ & $-2.51^{0}$ & $-2.38^{0}$ & $-2.17^{0}$ & 1.11 & 0.205 & $-2.71^{00}$ & -0.190 & -1.23 \\
\hline & $\mathrm{p}$ & 0.012 & 0.167 & 0.296 & 0.271 & 0.933 & 0.065 & 0.841 & 0.218 \\
\hline
\end{tabular}

Significance levels: U22 = 150, U13 = 45; U7 = 8; z0,05 = 1,96; z 0,01 = 2,58; 1 (Satu Mare F.D., Livada F.D., Şomcuta Mare F.D.); 2 (Lechința F.D., Bistrița F.D., Beclean F.D., Cluj F.D., Gherla F.D.)

Table 5. Annual mortality rate

\begin{tabular}{|c|c|c|c|c|c|c|}
\hline No. & $\begin{array}{l}\text { County Forest } \\
\text { Administration }\end{array}$ & $\begin{array}{l}\text { Forest } \\
\text { district }\end{array}$ & $\begin{array}{c}\text { Management } \\
\text { Unit/ compartment }\end{array}$ & $\begin{array}{c}\text { Theoretical annual } \\
\text { mortality rates } \\
(\text { Rmt })\end{array}$ & $\begin{array}{l}\text { Real annual mortality } \\
\text { rates }(R m r)\end{array}$ & $\begin{array}{c}\text { Difference } \\
(\%)(R m t)-(R m r)\end{array}$ \\
\hline 0 & 1 & 2 & 3 & 4 & 5 & 6 \\
\hline 1 & \multirow{4}{*}{ Satu Mare } & \multirow{2}{*}{ Satu Mare } & UP I. ua $56 \mathrm{~A}$ & 0.754 & 0.819 & 8.6 \\
\hline 2 & & & UP I. ua $34 \mathrm{C}$ & 0.675 & 0.757 & 12.1 \\
\hline 3 & & \multirow{2}{*}{ Livada } & UP I. 34A & 0.688 & 0.673 & -2.2 \\
\hline 4 & & & UP I. 69 & 0.688 & 0.699 & 1.6 \\
\hline 5 & \multirow{5}{*}{ Maramures } & \multirow{3}{*}{ Şomcuta Mare } & UP IV. ua 34 & 0.696 & 0.692 & -0.6 \\
\hline 6 & & & UP IV.ua 55B & 0.68 & 0.721 & 6.0 \\
\hline 7 & & & UP IV. ua 65 & 0.68 & 0.717 & 5.4 \\
\hline 8 & & \multirow{2}{*}{ Ulmeni } & UP I. ua 29 C & 0.673 & 0.723 & 7.4 \\
\hline 9 & & & UP I. ua $30 \mathrm{D}$ & 0.681 & 0.649 & -4.7 \\
\hline 10 & \multirow{5}{*}{ Bistrița } & \multirow{2}{*}{ Bistrița } & UP I. ua 407 & 0.686 & 0.698 & 1.7 \\
\hline 11 & & & UP VII. ua 151B & 0.686 & 0.672 & -2.0 \\
\hline 12 & & \multirow{3}{*}{ Beclean } & UP IV. ua 140B & 0.681 & 0.656 & -3.7 \\
\hline 13 & & & UP IV. ua 141B & 0.678 & 0.681 & 0.4 \\
\hline 14 & & & UP IV. ua 154C & 0.677 & 0.669 & -1.2 \\
\hline 15 & \multirow{2}{*}{ Cluj } & Cluj Napoca & UP II. u.a. 5A & 0.623 & 0.644 & 3.4 \\
\hline 16 & & Gherla & UP IV. ua 131 & 0.699 & 0.719 & 2.9 \\
\hline 17 & \multirow{6}{*}{ INCDS } & \multirow{6}{*}{ Lechința } & UP I. ua 63 B & 0.688 & 0.72 & 4.7 \\
\hline 18 & & & UP I. ua 65 C & 0.684 & 0.697 & 1.9 \\
\hline 19 & & & UP II. ua 21 B & 0.683 & 0.662 & -3.1 \\
\hline 20 & & & UP IV. ua29 D & 0.683 & 0.737 & 7.9 \\
\hline 21 & & & UP V. ua 28 D & 0.688 & 0.887 & 28.9 \\
\hline 22 & & & UP VI. ua 25D & 0.688 & 0.923 & 34.2 \\
\hline
\end{tabular}

Table 6. Correlation determination between differences recorded in 2013 and 2015 for the analyzed predictors, using the Spearman test

\begin{tabular}{|c|c|c|c|c|c|c|}
\hline Analyzed characteristic & Defoliation \% & $\begin{array}{c}\text { Slander } \\
\text { branches \% }\end{array}$ & $\begin{array}{l}\text { Thick } \\
\text { branches }\end{array}$ & $\begin{array}{c}\text { Vegetation state/ } \\
\text { vitality }\end{array}$ & $\begin{array}{c}\text { Degree of } \\
\text { devitalization }\end{array}$ & $\begin{array}{c}\text { Synthetic Damage } \\
\text { Index }\end{array}$ \\
\hline Slander branches \% & -0.051 & & & & & \\
\hline Thick branches & -0.051 & -0.123 & & & & \\
\hline Vegetation state/vitality & -0.025 & $-0.591^{*}$ & -0.055 & & & \\
\hline Degree of bevitalization & 0.163 & $-0.388^{*}$ & 0.165 & $-0.515^{*}$ & & \\
\hline Synthetic Damage Index & 0.158 & $0.372^{*}$ & -0.082 & -0.238 & $0.404^{*}$ & \\
\hline Annual mortality rates & 0.067 & 0.176 & $-0.486^{*}$ & 0.238 & -0.089 & 0.257 \\
\hline
\end{tabular}


630

The results obtained are in accordance with data of Kuźmiński and Wtykło (2014), determining that the deteriorating health conditions of oak stands were caused by greater defoliation; it was found that the deterioration increased in the second year of the study interval, due to the conditions of trees that slightly changed.

\section{Conclusions}

Stand decline can be assigned to structural or functional disorders, in which several categories of disturbing or harming factors concur and interact in different ways and directions, whose result is the weakening of tree vigor and culminating with their death. In a general meaning, the stand decline phenomenon can be defined as the totality of effects that harm a normal tree and stand vegetation state. The most important short and medium term decline predictors are those that render crown changes, regarding its shape, size or transparency. Even though all stands chosen for the study were affected by different disturbing factors, decline was not the case in all the situations. Only in 7 out of 22 stands the overcoming of the incipient stage and beginning of active dieback stage was observed. Positive significant changes were recorded for the degree of dieback, decline and devitalization predictors for the stands located in the vegetation level of sessile oak. For all the other stands, positive significant changes were not statistically ensured, and the positive change of some parameters was mostly due to climate factors. In the case of stands IV 29D and V 28D Lechința, the significant worsening was due to pest attacks (Agrillus sp. bark beetle), while in Cluj, II 5A it was due to the extension of mixed species. A positive significant correlation exists between the evolution of the general vegetation state and the percentage of dead slender branches, while a negative significant correlation exists between the vegetation state and the degree of devitalization or between thick branches and annual mortality rate. The evolution in time and the prognosis of tree mortality when negative phenomena occur can be expressed with the highest accuracy using the Synthetic Index Damage. It proved to be an adequate and reliable predictor for monitoring the health and vegetation state of stands.

\section{References}

Alexe A (1986). Analiza sistemica a fenomenului de uscare a cvercineelor și cauzele acesteia [Systemic analysis of the phenomenon and the causes of drying the quercus species]. Revista Pădurilor 101:19-23.

Andersson M, MilbergP, Bergman KO (2011). Low pre-death growth rates of oak (Quercus robur L.) - Is oak death a long-term process induced by dryyears? Annals of ForestScience 68(1):159-168.

Brown N, Jeger M, Kirk S, Williams D, Xu X, Pautasso M, Denman S (2017). Acute oak dedine and Agrilus biguttatus: The co-occurrence of stem bleeding and D-shaped emergence holes in Great Britain. Forests 8(3):87.

Ciesla WM, Donaubauer E (1994).Decline and dieback of trees and forests, aglobal overview. FAO Paper 120.

Csóka G, Tóth J, Koltay A (1999). Trends of sessile oak decline in NorthEastern Hungary. Methodology of forest insect and disease survey in Central Europe. Proceedings of the Second Workshop of the IUFRO WP7.03.10.
Delatour C (1983). Les dépérissements de chênes en Europe. Revue Forestière Française vol XXXV(4):265-282.

Denman S, Brown N, Kirk S, Jeger M, Webber J (2014). A description of the symptoms of acute oak decline in Britain and a comparative review on causes of similar disorders on oak in Europe. Forestry 87(4):535-551.

Denman S, Barrett G, Kirk SA, McDonald JE, Coetzee MPA (2017). Identification of Armillaria species on declined oak in Britain: Implications for oak health. Forestry: An International Journal of Forest Research pp 4:14.

Desprez-Loustau ML, Marçais B, Nageleisen LM, Piou D, Vannini A (2006). Interactive effects of drought and pathogens in forest trees. Annals of Forest Science 63(6):597-612.

Dmyterko E, Bruchwald A (2000). Methodical grounds for assessing damage to oak stands. Conference in Warsaw, Poland, Forest Research Institute pp 53-64.

Dubravac T, Dekanic S (2009). Structure and dynamics of the harvest of dead and declining trees of penduculate oak in the stands of Spacva forest from 1996 to 2006. Sumarkki List 133:391-405.

Fodor E, Timofte A, Gembasu T (2011). Mycorrhizal status of several Quercus species in Romania (Quercus cerris, Q. frainetto, Q. robur) and the optimization perspective of growth conditions for in vitro propagated plants transplanted in the field. Annals of Forest Research 54(1):3.

Führer E (1998). Forest decline in Central Europe: additional aspects of ist cause. Forest Ecology and Management 37:249-257.

Gibbs JN, Greig BJW (1997). Biotic and abiotic factors affecting the dyingback of pedunculate oak Querusrobur L. Forestry 70:399406.

Giurgiu V, Drăghiciu D (2004). Mathematical and auxological modelsstand production tables. Ed Ceres

Hajji M, Dreyer E, Marcais B (2009). Impact of Erysiphe alphitoides on transpiration and photosynthesis in Quercus robur leaves. European Journal of Plant Pathology 125:63-72.

Haring P, Crişan A, Fabian A, Fabian N (1984). Aspecte privind uscarea gorunului (Quercus petraea Lieb.) cauzată de ciuperca Ceratocystis fagacearum (Bretz.) Hunt. [Wilt disease of sessile oak (Quercus petraea Lieb.) caused by Ceratocystis fagacearum (Brezz) Hunt]. Contributii Botanicepp 77-85.

Hilszczański J, Sierpinski A (2006). Agrilus spp. the main factor of oak decline in Poland. IUFRO Working Party 7.03.10. Proceedings of the Workshop7910):121-125.

Jankowiak R, Stepniewska H, Bilański P, Kolařík M (2014). Occurrence of Phytophthora plurivora and other Phytophthora sp. in oaks forests of southern Poland and their association with site conditions and the health status of trees. Folia Microbiologica 59 (6):531-542

Jung TH, Blaschke HE (1996). Phytophthora root in declining forest trees. In: proceedings of the International Colloquium on „Bioindication of Forest Site Pollution: Development of Methodology and Training BIOFOSP.PHYTON-HORNpp 95-102

Keca N, Koufakis I, Dietershagen J, Nowakowska JA, Oszako T (2016). European oak decline phenomenon in relation to climatic changes. Folia Forestalia Polonica 58(3):170-177.

Kunca A, Zúbrik M, Galko J, Vakula J, Leontovyč R, Konôpka B, Nikolov 
C, Gubka A, Longauerová A, Malová M, Kaštier P, Rell S (2010). Salvage felling in the Slovak forests in the period 2004-2013. Forestry Journal 61(3):188-195.

Kuzminski R W, Wtiklo R (2014). Application of a synthetic tree damage index to assess changes in the health condition of selected oak stands in the Wloszakowice Forest Dvision. Acta Scientiarum Polonorum 13(2):49-57.

Marcu G(1986). Tipuri de cauze care au provocat uscarea stejarilor în diferite perioade și țări din Europa şi alte continente. [Types of cases which have caused drying of oaks in different periods and countries in Europe and other continents]. Revista Pădurilor 3:1421.

McManus M, Csóka G (2007). History and impact of gypsy moth in North America and comparison to recent outbreaks in Europe. Acta Silvatica et Lignaria Hungarica 3:47-64.

Millar CI, Stephenson NL (2015). Temperate forest health in an era of emergingmegadisturbance. Science 349:823-826.

Neuwirth B, Schweingruber FH, Winiger M (2007). Spatial patterns of central European pointer years from 1901 to 1971. Dendrochronologia 24:79-89.

Pap P, Drekić M, Poljaković-Pajnik L, Marković M, Vasić V (2014a). The most important insect pests in forest ecosystems of Vojvodina and their suppression during the period 2004-2013. Silva Balcanica 15(2):68-80.

Pap P, Stoinić S, Nikolić N, Orlović S, Marković M, Vasić V, Stevanov M (2014b). Impact of Erysiphe alphitoides (Griffon and Maubl.) U. Braun and S. Takam on leaf physiological parameters in pedunculate oak. Baltic Forestry20(1):2-9.

Pešková V, Lorenc F, Modlinger R, Pokorná V (2015). Impact of drought and stand edge on mycorrhizal density on the fine roots of Norway spruce. Annals of Forest Research 58:245.

Popa I, Leca S, Crăciunescu A, Sidor C, Badea O (2013). Dendroclimatic response variability of Quercus species in the Romanian intensive forest monitoring network. Notulae Botanicae Horti Agrobotanici ClujNapoca 41(1):326-332.

Raftoyannis Y, Spanos I, Radoglou K (2008). The decline of Greek fir (Abies cephalonica Loudon): Relationships with root condition. Plant Biosystems 142(2):386-390.

Rossnev B, Petkov P, Georgiev D (1994). Importance and character of the tracheomycotic disease in the oak forests of Bulgaria. Nauka za Gorata 31(1):49-54.

Salle A, Nageleisen LM, Lieutier F (2014). Bark and wood boring insects involved in oak declines in Europe: Current knowledge and future prospects in a context of climate change. Forest Ecology and Management 328:79-93.
Santini A, Ghelardini L, Pace CD, Desprez-Loustau ML, Capretti P, Chandelier A, Cech T, Chira D, Diamandis S, Gaitniekis T, Hantula J (2013). Biogeographical patterns and determinants of invasion by forest pathogens in Europe. New Phytologist 197(1):238-50.

Sheil D, May RM (1996). Mortality and recruitment rate evaluations in heterogeneous tropical forests. Journal of Ecology 84:91-100.

Sohar K, Helama S, Läänelaid A, Raisio J, Tuomenvirta H (2013). Oak decline in a southern Finnish forest as affected by a drought sequence. Geochronometria 41(1):92-103.

Sonesson K, Drobyshev I (2010). Recent advances on oak decline in southern Sweden. Ecological Bulletins 53:197-207.

Stringer JW, Kimmerer TW, Overstreet JC, Dunn JP (1989). Oak mortality in eastern Kentucky. Southern Journal of Applied Forestry 13(2):86-91.

Szewczyk W, Dudek M, Baranowska M (2011). Evaluation of oak tree condition on the basis of losses in the assimilation aparatus of selected oak stands in Sulecin Forest District. Acta Scientiarum Polonorum 10(3):37-47.

Thomas FM (2008). Recent advances in cause-effect research on oak decline in Europe. CAB Reviews: Perspectives in Agriculture, Veterinary Science, Nutrition and Natural Resources 3(037):1-12.

Thomas FM, Blank R, Hartmann G (2002). Abiotic and biotic factors and their interactions as causes of oak decline in Central Europe. Forest Pathology32(4-5):277-307.

Trudic B, Galovic V, Orlovic S, Papand P, Pekec S (2013). A strategy for the identification of a canditate gene for drought induced stress in penduculate oak (Quercus robur L. (Q. pedunculata Ehrh.)), Fagaceae. Bulgarian Journal of Agricultural Science 19(2):338-346.

Tulic M, Bijak S (2016). Are climatic factors responsible for the process of oak decline in Poland? Dendrochronologia 38:18-25.

Voelker LS, Muzika RM, Guyette PR (2008). Individual tree and stand level influences on the growth, vigor, and decline of red oaks in the Ozarks. Forest Science 54(1):8-20.

Vuts J, Woodcock CM, Sumner ME, Caulfield JC, Reed K, Inward DJG, Leather SR, Pickett JA, Birkett MA, Denman S (2016). Responses of the two-spotted oak buprestid, Agrilus biguttatus (Coleoptera: Buprestidae), to host tree volatiles. Pest Management Science 72(4):845851.

WooSY (2009). Forest decline of the world: A linkage with air pollution and global warming. African Journal of Biotechnology 8(25):7409-7414. 